\title{
Determinant of Village Fund Management Accountability
}

\author{
Nela Safelia Primadi Prasetio Afrizal* \\ Faculty of Economics and Business of Jambi University, Jambi, Indonesia
}

\begin{abstract}
This research aims to analyze the effect of fund tax compliance, the application of the SISKEUDES application, and the competence of village apparatus on the accountability of government assistance fund management. Muaro Jambi District in Jambi Luar Kota District. The population in this study were all village fund managers, 20 villages in Jambi Luar Kota District, Muaro Jambi Regency. Determination of the research sample using a purposive sampling method and based on certain criteria. The analytical technique used is multiple regression analysis. The results show that fund tax compliance does not impact the accountability of government assistance fund management. At the same time, the application of the siskeudes application and the competence of the village apparatus affected the accountability of government assistance fund management in Muaro Jambi Regency.
\end{abstract}

Keywords: Tax Compliance, Village Apparatus Competence, Accountabiliy.

DOI: $10.7176 / \mathrm{RJFA} / 13-2-05$

Publication date: January $31^{\text {st }} 2022$

\section{INTRODUCTION}

\subsection{Background}

Regional autonomy is an act of the central government to give freedom to the regions in managing all the interests of their respective regions (Yunianti, 2015 in Juardi, Muchlis \& Putri, 2018). According to Law Number 6 of 2014 development must begin in the smallest unit of government, namely the village. Village development is a program mentioned by the government through the Nawacita program that is committed to developing Indonesia from the periphery. So that to realize development in the village, a large number of funds are needed, sourced from village expenditure financing, namely the Village Fund (DJPK, 2017).

Law Number 6 of 2014 explains that managing village finances must be based on taking into account the principles of accountability, transparency, and carried out in an orderly manner. Accountability is not just formal financial accountability to the public, but also includes accountability for compliance with regulations, organizational environment, society, and government (Mahayani, 2017 in Ardianti \& Suartana, 2020).

Regulation of the Minister of Home Affairs Number 20 of 2018 article 58 states that the Finance Department as a tax collector shall withhold taxes on Village treasury expenditures and must deposit all tax revenues collected by the provisions of the legislation. So in this case, financial management includes tax matters.

BPKP in supporting financial management activities makes applications that aim to improve the quality of village financial governance. This application is the Siskeudes Application or the Village Financial System Application, in anticipation of the implementation of Law Number 6 of 2014 concerning Villages (Luthfiani, Asmony \& Herwanti, 2020). So in this case the competence of village officials in understanding the implementation of village accounting is needed to realize village fund management accountability. Research results still show that there are still many government organizations or institutions that have not been able to realize the demands for accountability for village fund management (Gayatri \& Komang, 2017).

Muaro Jambi Regency has 150 villages in 11 sub-districts, in 2018 the total village fund of Muaro Jambi Regency reached Rp 120 billion. However, only 140 villages received village funds that year. According to Budi Hartono as the Head of the Muaro Jambi Regency Inspectorate, he stated that there were irregularities in village funds in 32 villages. the findings of irregularities in village funds are administrative in nature and physical development (www.beritasatu.com). So in this case the researcher is interested in researching the Jambi Outer City sub-district, Muaro Jambi Regency.

\subsection{Research Problems}

1. Does Tax Compliance Affect Village Fund Management Accountability?

2. Does the Village Financial System Application (SISKEUDES) Affect Village Fund Management Accountability?

3. Does the Competence of Village Apparatus Affect the Accountability of Village Fund Management?

\subsection{Research Specific Purpose}

The purpose of this study was to examine the effect of tax compliance, the application of the SISKEUDES application, and the competence of village officials on the accountability of village fund management. 


\subsection{Research Urgency}

From the background and research objectives above, the urgency in this research is to be able to provide input for village officials about factors in determining village fund accountability in making decisions. As for the government as a consideration in making laws.

\section{LITERATURE REVIEWS}

\section{Agency theory}

Agency theory explains the relationship between business principals and their stakeholders (agents) who are resource holders. In other words, agents are decision-makers who make day-to-day decisions but do not bear any kind of risk (Hill, CW, \& Jones 1992 in Kuma \& Yosuff, 2020).

\section{Stewardship Theory}

Stewardship theory is similar to agency theory which also analyzes how to ensure each task is more accountable. Stewardship theory focuses more on collective goals than individual goals. On the other hand, it is based on a logical and sociological analysis of human behavior and assumes that internal motivation helps explain behavior (Scillemans \& Bjurstrom, 2020).

\section{Village Fund Management Accountability}

Accountability is the obligation of the agent to be able to disclose, report, and account for all types of activities and activities carried out by the principal who has the right to be able to ask for such accountability (Mardismo, 2013).

\section{Tax Compliance}

Willingness to be able to do everything that is based on self-awareness or coercion so that one's behavior can be by expectations is called compliance. This relates to taxation, taxpayer compliance is the act of taxpayers in carrying out their tax obligations by applicable laws and regulations (Anggraeni 2013 in Heriningsih, Fitriyani \& Sudaryati, 2020).

\section{Village Financial System Application (SISKEUDES)}

A large number of village funds and government activities that continue to increase and become more complex every year make village officials as village management officers to be able to adapt to the use of financial information system technology. This application is called the Village Fund Financial System Application or abbreviated as siskeudes. The implementation of the siskeudes is expected to be able to bring about changes in the reporting process, accountability, and the level of participation of village officials in carrying out their duties to make it easier and more responsible (Bawono, Kinasih \& Rahayu, 2020).

\section{Village Apparatus Competence}

Competence is a skill and knowledge characterized by professionalism in a particular field (Wibowo, 2012). Knowledge (Knowledge), skills (Skills), and attitudes (Attitude) is a component of the formation of competence.

\section{Previous Research}

Research conducted by Heriningsih, Fitriyani \& Sudaryati (2020) shows that tax compliance can affect tax obligations, knowledge, and socialization which can affect the level of accountability. The results of research conducted by Bawono, Kinasih \& Rahayu (2020) stated that the application of the siskeudes application was able to become an intervention in the management of village funds by the village government in Banyumas Regency. The results of research conducted by Sari \& Aji (2020) state that the competence of village officials has a positive effect on the management of village funds in the Banyumas Regency.

\section{Research Framework and Model}

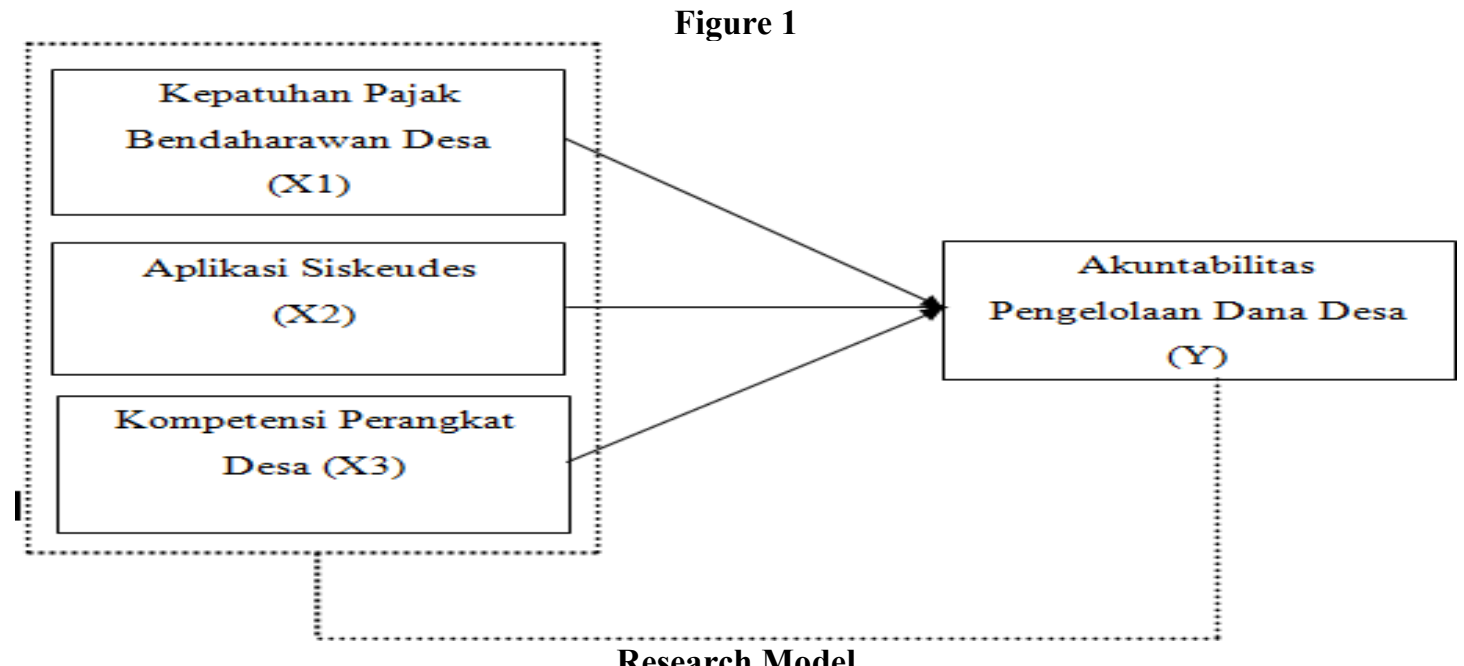

Research Model 
Through the Director-General of Taxes, the government demands to socialize to increase tax compliance. The village treasurer's compliance, which is based on stewardship theory, is designed to examine the situation in which executives as managers are motivated to be able to do the best for the organization.

The government through BPKP makes an application that is used to help the management of village funds, namely through the siskeudes application. Sulina, Wahyuni, \& Kurniawan (2017) state that the implementation of a good and correct siskeudes application will increase the accuracy of accountable and high-quality villages so that the higher the application of the siskeudes application, the higher the accountability of village fund management.

Jensen \& Meckling (1976) in Luthfiani, Asmony \& Herwanti (2020) state that the relationship between the owner of economic resources (principal) and manager (agent) in this case the village community plays the role of the principal in handing over the authority of managing village funds to the village government which acts as the principal. agents, and demanding agents to be able to carry out accountable management of village funds. Aulia, Agusti \& Julita (2018) and Rosyidi, Azlina, \& Putra (2018) show that the competence of village officials affects the accountability of village fund management.

Based on the description above, the hypotheses formulated are:

H1: Tax compliance has a significant effect on village fund management accountability

H2: The siskeudes application has a significant effect on the accountability of village fund management

H3: The competence of village officials has a significant effect on the accountability of village fund management

\section{RESEARCH METHODS}

\section{Types and Sources of Data Collection}

This type of research is descriptive quantitative research. This research was conducted on the village government in Muaro Jambi Regency. To test the hypothesis the numerical data is processed by statistical methods. The Source of data is primary data obtained from distributing questionnaires.

\section{Population and Sample}

The population in this study were village fund managers in 20 villages in the Jambi Outer City District, Muaro Jambi Regency. The technique of determining the nonprobability sampling sample is in the form of purposive sampling (Sugiyono, 2019). The sample criteria in this study were the village head, village secretary, head of financial affairs, head of development affairs, head of government affairs, and had worked for at least one year in the village administration.

\section{Research variable}

Table 2

Variable Operation

\begin{tabular}{|c|c|c|c|}
\hline No & Variable & Indicator & Scale \\
\hline 1 & $\begin{array}{l}\text { Independent Variable }(\mathrm{X}) \\
\text { X1: Tax Compliance }\end{array}$ & $\begin{array}{l}\text { Measured by looking at the timeliness of paying taxes, accuracy in } \\
\text { the amount, and right of tax liability (Luthfiani, 2020) }\end{array}$ & interval \\
\hline 2 & $\begin{array}{l}\text { Independent Variable }(\mathrm{X}) \\
\mathrm{X} 2 \text { : Siskeudes App }\end{array}$ & $\begin{array}{l}\text { It is measured by looking at the use of the siskeudes application, } \\
\text { seen from the ability to input, process, store, and organize data } \\
\text { (Luthfiani, 2020). }\end{array}$ & interval \\
\hline 3 & $\begin{array}{l}\text { Independent Variable }(\mathrm{X}) \\
\mathrm{X} 3 \text { : Village Apparatus } \\
\text { Competence }\end{array}$ & $\begin{array}{l}\text { It is measured by knowledge, skills, abilities, friendliness, and } \\
\text { courtesy to the community (Mada et al. 2017). }\end{array}$ & interval \\
\hline 4 & $\begin{array}{l}\text { Dependent Variable }(\mathrm{Y}) \\
\text { Village } \quad \text { Fund } \\
\text { Management } \\
\text { Accountability }\end{array}$ & $\begin{array}{l}\text { Measured using } 5 \text { indicators (Mada et al. 2017) } \\
\text { - Honesty and Information Disclosure. } \\
\text { - Compliance in reporting. } \\
\text { - Compliance with procedures. } \\
\text { - Information sufficiency. } \\
\text { - Accuracy in submitting reports. }\end{array}$ & Interval \\
\hline
\end{tabular}

\section{Data Analysis Method}

Methods of data collection using a questionnaire with a Likert scale. Analysis The data analysis used is multiple linear regression analysis with stages of validity test, reliability test, classical assumption test, and hypothesis testing which includes partial test $(\mathrm{t})$, simultaneous test $(\mathrm{F})$, and coefficient of determination test (R2). This multiple linear regression analysis was used to determine the village treasurer's tax compliance, the siskeudes application, and the competence of village officials to the accountability of village fund management, with the following equation formula:

$$
\mathrm{Y}=+1 \mathrm{X} 2+2 \mathrm{X} 2+3 \mathrm{X} 3+\varepsilon
$$




\section{RESULTS AND DISCUSSION}

Validity and Reliability Test Results

From the results of the research using SPSS, it is known that all questions are valid with a significance value smaller than the alpha $(\alpha) 0.05$ so that all statement items can be used for research. Testing the reliability of the village treasurer's tax compliance obtained Cronbach's Alpha value of $0.727>0.70$ indicating that this research variable is reliable. The village financial system application variable (SISKEUDES) resulted in a Cronbach's Alpha value of $0.879>0.70$ indicating that this research variable was reliable. The village apparatus competency variable resulted in Cronbach's Alpha value of $0.858>0.70$ indicating that this research variable was reliable. And the village fund management accountability variable produces Cronbach's Alpha value of $0.909>0$,

Classic Assumption Test Results

Normality test

Table 3

Kolmogorov-Smirnov Test . Normality Test Results

\begin{tabular}{|l|l|r|}
\hline \multicolumn{2}{|c|}{ One-Sample Kolmogorov-Smirnov Test } \\
\hline N & & Unstandardized Residual \\
\hline Normal Parameters, b & & 90 \\
\hline & mean & .0000000 \\
\hline Most Extreme Differences & Std. Deviation & 3.60111992 \\
\hline & Absolute & .082 \\
\hline & Positive & .082 \\
\hline Test Statistics & negative & -.064 \\
\hline asyimp. Sig. (2-tailed) & & .082 \\
\hline
\end{tabular}

The results of the normality test using the Kolmogorov-Smirnov method obtained a significance result from the normality test of 0.189 which shows this result is greater than the 0.05 significance level. So it can be concluded that the data taken is normally distributed.

\section{Multicollinearity Test}

Table 4

Multicollinearity Test Results

\begin{tabular}{|c|l|r|r|}
\hline \multicolumn{2}{|c|}{ Model } & \multicolumn{2}{c|}{ Coefficients } \\
\cline { 2 - 4 } \multicolumn{2}{|c|}{} & \multicolumn{2}{c|}{ Collinearity Statistics } \\
\hline \multirow{3}{*}{1} & Tax compliance & .988 & \multicolumn{1}{c|}{ VIF } \\
\cline { 2 - 4 } & SISKEUDES & .945 & 1.012 \\
\cline { 2 - 4 } & Village apparatus competence & .955 & 1.058 \\
\hline
\end{tabular}

The results of the multicollinearity test show that the tolerance value of each variable is greater than 0.01 and shows the VIF value of each variable is less than 10, so it can be stated that there is no multicollinearity between independent variables.

\section{Heteroscedasticity Test}

Figure 2

Heteroscedasticity Test Results with Scatterplot Graph Test

Scatterplot

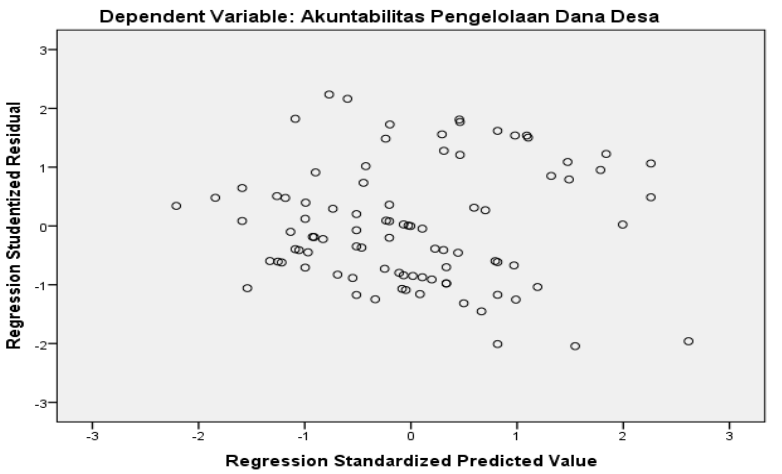

The scatterplot graph above shows that the data points spread above and below or around the number 0 , the points do not just gather at one point and the spread of the points is not patterned. Thus, it can be concluded that there is no heteroscedasticity problem in this regression model. 
Multiple Linear Regression Analysis Test Results

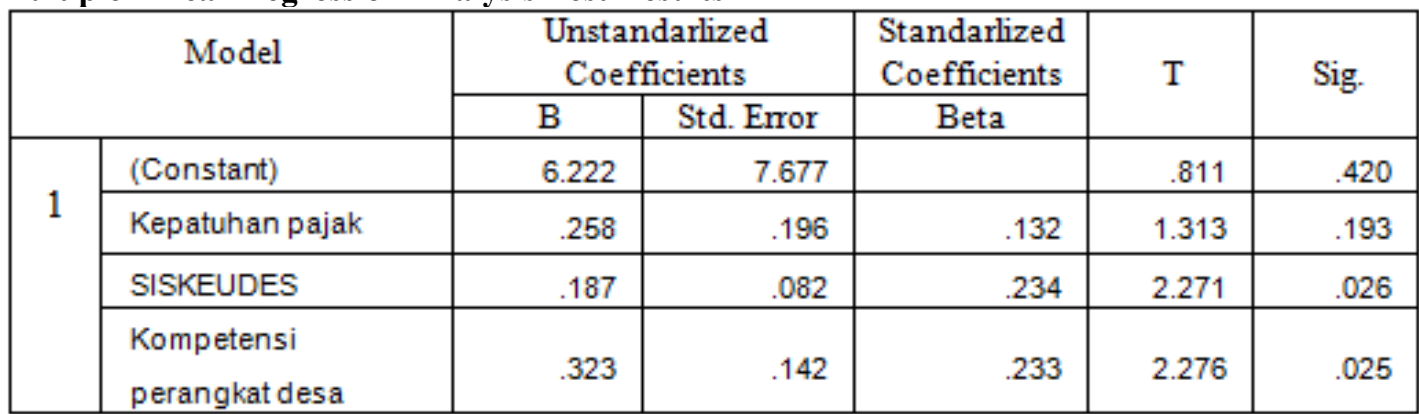

$\mathrm{Y}=6,222+0.258$ Tax Compliance +0.187 Village Financial System Application (SISKEUDES) +0.323 Village Apparatus Competence +

Hypothesis test

Simultaneous Test Results (F)

\begin{tabular}{|c|l|r|r|r|r|r|}
\hline \multicolumn{7}{|c|}{ ANOVA $^{2}$} \\
\hline \multirow{3}{*}{1} & $\begin{array}{c}\text { Sum of } \\
\text { Squares }\end{array}$ & \multicolumn{1}{c|}{ Df } & $\begin{array}{c}\text { Mean } \\
\text { Square }\end{array}$ & F & Sig. \\
\hline & Regression & 188.831 & 3 & 62.944 & 4.690 & $.004^{\circ}$ \\
\cline { 2 - 8 } & Residual & 1154.158 & 86 & 13.420 & & \\
\cline { 2 - 8 } & Total & 1342.989 & 89 & & & \\
\hline
\end{tabular}

Table 4.8 shows that the significance level (Sig.) is $0.004<0.05$, then this model test is feasible to be used in research and has a simultaneous effect.

Partial Test Results (t)

\begin{tabular}{|c|c|c|c|c|c|c|}
\hline \multirow{2}{*}{\multicolumn{2}{|c|}{ Model }} & \multicolumn{2}{|c|}{$\begin{array}{l}\text { Unstandarlized } \\
\text { Coefficients }\end{array}$} & \multirow{2}{*}{$\begin{array}{c}\begin{array}{c}\text { Standarlized } \\
\text { Coefficients }\end{array} \\
\text { Beta } \\
\end{array}$} & \multirow[t]{2}{*}{$\mathrm{T}$} & \multirow[t]{2}{*}{ Sig. } \\
\hline & & $\mathrm{B}$ & Std. Error & & & \\
\hline \multirow{4}{*}{1} & (Constant) & 6.222 & 7.677 & & .811 & .420 \\
\hline & Kepatuhan pajak & .258 & .196 & .132 & 1.313 & .193 \\
\hline & SISKEUDES & .187 & .082 & .234 & 2.271 & .026 \\
\hline & $\begin{array}{l}\text { Kompetensi } \\
\text { perangkat desa }\end{array}$ & .323 & .142 & .233 & 2.276 & .025 \\
\hline
\end{tabular}

Based on the table, it can be concluded that the village treasurer's tax compliance variable (X1) has a significant level of $0.193>0.05$, so the first hypothesis is rejected, so that the village treasurer's tax compliance (X1) does not affect the village fund management accountability (Y). The SISKEUDES application variable (X2) has a significant level of $0.026<0.05$, so the second hypothesis is accepted so that the SISKEUDES application (X2) influences Village Fund Management Accountability (Y). The village apparatus competency variable (X3) has a significant level of $0.025<0.05$, so the third hypothesis is accepted so that the village apparatus competency (X3) influences village fund management accountability $(\mathrm{Y})$.

\section{DISCUSSION}

\section{The Effect of Tax Compliance on Village Fund Management Accountability}

The results of the tests carried out show that the significance level is $0.193>0.05$, so this indicates that tax compliance does not significantly affect the accountability of village fund management. The results of this study contradict the stewardship theory. Stewardship theory focuses more on collective goals than individual goals. On the other hand, it is based on a logical and sociological analysis of human behavior and assumes that internal motivation helps explain behavior (Scillemans \& Bjurstrom, 2020). Stewardship theory describes where there are no management conditions or situations that are motivated for personal goals but only focus on organizational interests (Luthfiani, Asmony \& Herwanti 2020).

Effect of Village Financial System Application (SISKEUDES) on Village Fund Management Accountability The results of the tests carried out show that the significance level is $0.026<0.05$, so this indicates that the SIKEUDES application has a significant effect on the accountability of village fund management. The results of this test are by the Agency Theory. Agency theory explains the relationship between business principals and their 
stakeholders (agents) who are resource holders. An agency relationship occurs when a person's contract as a principal and someone as an agent performs services for the principal's interest in managing his wealth (Saputra, Dewi, Larasdiputra, Manurung \& Amani, 2020). For this reason, the siskeudes application as an information technology system that is easy to understand greatly helps the performance of village officials in the implementation of village fund management. The results of this study are in line with research conducted by Bawono, Kinasih \& Rahayu (2020) which states that the application of the siskeudes application can become an intervening in the management of village funds by the village government in Banyumas Regency. And in line with research conducted by Luthfiani, Asmony \& Herwanti which states that the siskeudes application has a positive effect on village fund management accountability.

The Influence of Village Apparatus Competence on Village Fund Management Accountability

The results of the tests carried out show that the significance level is $0.025<0.05$, so this indicates that the competence of village officials has a significant effect on the accountability of village fund management. The results of this study are by the stewardship theory, namely, the role of village managers or officials will be related to the main goals of the organization and the commitment of village officials to always prioritize common interests above personal interests. So that village officials will have the motivation to carry out their duties properly to ensure the accountability of village funds can be accounted for. This research is in line with research conducted by Sari \& Aji (2020) which states that the competence of village officials has a positive effect on the management of village funds in Banyumas Regency.

\section{CONCLUSION}

The main priority of the Village Government at this time is to realize accountability in the management of village funds. Village financial management is a cycle that includes planning, implementation, administration, reporting, and accountability. The results of the research conducted showed that there was no effect of village treasurer tax compliance on the accountability of village fund management. While the siskeudes application and village apparatus competence affect the accountability of village fund management.

The village government is expected to continue to improve village treasurer tax compliance, siskeudes application, and village apparatus competence, so that the application of agency theory and stewardship theory regarding information disclosure about village fund management that will be submitted by the village government as an agent can be well received by the principal.

\section{REFERENCES}

[1] Ardianti, P.A.R. \& Suartana, I W. (2020). Kompetensi Sumber Daya Manusia dan Impementasi Sistem Keuangan Desa dan Akuntabilitas Pengelolaan Dana Desa. E-Jurnal Akuntansi, 30(11), 2839-2851.

[2] Aulia, P., Agusti, R., \& Julita, J. (2018). Pengaruh kompetensi aparat pengelola dana desa, komitmen organisasi pemerintah desa, pemanfaatan teknologi informasi, dan partisipasi masyarakat terhadap akuntabilitas pengelolaandana desa di Kabupaten 50 Kota (Studi empiris pada Kecamatan Harau, Kecamatan Pangkalan Koto Baru, dan Kecamatan Kapur Ix). Jurnal Online Mahasiswa (JOM) Bidang Ilmu Ekonomi, 1(1), 1-15.

[3] Bawono, I.R., Kinasih, A.D.M., \& Rahayu, A.K. (2020). Factors Affecting Accountability of Village Fund Management through Implementation of the Village Financial System (SISKEUDES). Journal of Accounting and Investment, 21(3), 71-91.

[4] Direktorat Jendral Perimbangan Keuangan. (2017). Buku Pintar Dana Desa. Kementerian Keuangan Republik Indonesia, Jakarta.

[5] Gayatri, dan Komang A.J.P.D. (2019). Faktor-Faktor yang Berpengaruh Pada Akuntabilitas Pengelolaan Dana Desa. E- Jurnal Akuntansi Universitas Udayana. Vol. 26. ISSN: 2302-8556.

[6] Heriningsih, S., Fitriyani, L.Y., \& Sudaryati, D. (2020). Determinants Of Tax Compliance Behaviour (Empirical Studies In Bantul Regency). International Journal of Economics, Business and Management Research, 4(7), ISSN: 2456-7760.

[7] Kuma, F.K., \& Yosuff, M.E. (2020). The Dynamics Of Pecking Order And AgencyTheories On Crowdfunding Concept As Alternate Finance For Start-Up Businesses. International Journal of Technology and Management Research. 4(1), ISSN $2026-6480$.

[8] Luthfiani, B.M., Asmony, T., \& Herwanti, R.T. (2020). Analisis Faktor-Faktor yang Mempengaruhi Akuntabilitas Pengelolaan Dana Desa di Kabupaten Lombok Tengah. e-Jurnal Akuntansi. 30(7), e-ISSN $2302-8556$

[9] Mada, S., Kalangi, L., \& Gamaliel, H. (2017). Pengaruh Kompetensi Aparat Pengelola Dana Desa, Komitmen Organisasi Pemerintah Desa, dan Partisipasi Masyarakat Terhadap Akuntabilitas Pengelolaan Dana Desa Di Kabupaten Gorontalo. Jurnal Riset Akuntansi dan Auditing. Hal. 106-115.

[10] Mardiasmo. (2013). Reformasi Pengelolaan Keuangan Publik Menuju Akuntabilitas Publik. Makalah yang Disampaikan dalam Kongres Ikatan Sarjana Ekonomi Indonesia (ISES), Makasar. No. 12. Hal. 248-265.

[11] Permendagri Nomor 20 Tahun 2018 Tentang Pengelolaan Keuangan Desa 
[12] Rosyidi, M., Azlina, N., \& Putra, A. A. (2018). Pengaruh transparansi, kompetensi dan sistem pengendalian internal terhadap akuntabilitas Pemerintah Desa dalam pengelolaan Alokasi Dana Desa (Studi empiris pada seluruh Desa di Kecamatan Salo Kabupaten Kampar). Jurnal Online Bidang Ilmu Ekonomi, 1(1), 1-14.

[13] Saragih, Radesman. (2019). Pengelolaan Dana Desa di Muaro Jambi Banyak Menyimpang. https://www.beritasatu.com/nasional/563153/pengelolaan- dana-desa-di-muarojambi-banyak-menyimpang. (diakses 27 Februari 2021)

[14] Sari, K.D.C., \& Aji, A.B. (2020). Analysis Competence Of Village Officials On The Performance Of Village Fund Management In Banyumas Regency. International Journal of Economics, Business, and Accounting Research(IJEBAR), Vol. 4, E-ISSN: 2614-1280 P-ISSN 2622-4771.

[15] Schillemans, Thomas \& Bjurstrom K.H. (2020). Trust and verification: balancing agency and stewardship theory in the governance of agencies. International Public Management Journal. 23(5), 650-676.

[16] Sugiyono. (2019). Metode Penelitian Kuantitatif Kualitatif dan R\&D. Bandung: Alfabeta.

[17] Sulina, G.A.T, Wahyuni, M.A, \& Kurniawan, P.S. (2017). Peranan Sistem Keuangan Desa (SISKEUDES) Terhadap Kinerja Pemerintah Desa (Studi Kasus di Desa Kaba-kaba, Kecamatan Kediri, Kabupaten Tabanan). e- Journal Universitas Pendidikan Ganesha. Jurnal Akuntansi. 8 (1),1 12.

[18] Undang-Undang Nomor 6 Tahun 2014 Tentang Desa

[19] Wibowo. (2012). Manajemen Kinerja. Edisi Ketiga. Rajawali Pres. Depok.

Author: Afrizal (D’04-D'08--CH '15--‘19). Dean of Economics Faculty of Jambi University (2004-2008), Dean of Economics Faculty of Jambi University (2008-2012), Chairman of Indonesia Accountants Institute for Jambi Province (2015-2019). Birth: 27 July 1969 Bukittinggi, Indonesia. Education: Bachelor in Accounting at Andalas University, Padang, Indonesia. Master in Accounting 1996 at Padjadjaran University, Bandung, Indonesia. Doctor in Accounting 1999 at Padjadjaran University, Bandung, Indonesia. 